\section{The strangest of all encounters: racial and ethnic discrimination in US health care}

\author{
O encontro mais estranho de todos: \\ discriminação étnica e racial no sistema de saúde \\ dos Estados Unidos
}

\author{
El más extraño de todos los encuentros: \\ discriminación racial y étnica en la atención de \\ salud en los Estados Unidos
}

Sherman A. James 1

doi: 10.1590/0102-311X00104416

\begin{abstract}
In 2003, a Committee of the Institute of Medicine of the National Academy of Sciences summarized hundreds of studies documenting that US racial minorities, especially African Americans, receive poorer quality health care for a wide variety of conditions than their White counterparts. These racial differences in health care persist after controlling for sociodemographic factors and patients' ability to pay for care. The Committee concluded that physicians' unconscious negative stereotypes of African Americans, and perhaps other people of color, likely contribute to these health care disparities. This paper selectively reviews studies published after 2003 on the likely contribution of physicians' unconscious bias to US health care disparities. All studies used the Implicit Association Test which quantifies the relative speed with which individuals associate positive attributes like "intelligent" with Whites compared to Blacks or Latino/as. In addition to assessing physicians' unconscious attitudes toward patients, some studies focused on the behavioral and affective dimensions of doctor-patient communication, such as physicians' "verbal dominance" and whether patients felt respected. Studies reviewed found a "pro-white" unconscious bias in physicians' attitudes toward and interactions with patients, though some evidence suggests that Black and female physicians may be less prone to such bias. Limited social contact between White physicians and racial/ethnic minorities outside of medical settings, plus severe time pressures physicians often face during encounters with patients who have complex health problems could heighten their susceptibility to unconscious bias.
\end{abstract}

Delivery of Health Care; Ethnicity and Health; Racism
Correspondence

S. A. James

Emory University.

1518 Clifton Road NE, Atlanta / Georgia - 30322, U.S.A.

Sherman.James@emory.edu

1 Emory University, Atlanta, U.S.A. 
"Of all the forms of inequality, injustice in health care is the most shocking and inhumane" (Martin Luther King, Jr., Chicago, USA, 1966).

\section{Introduction}

No one could have said it better. When Dr. Martin Luther King, Jr. was invited to address the 1966 National Convention of the Medical Committee for Human Rights (MCHR), he denounced social injustice in health care as, arguably, the most inhumane form of inequality. The MCHR ${ }^{1}$ was an interracial organization of physicians who provided free medical care to civil rights workers across the US South during some of the most dangerous years of the 1960s Civil Rights Movement. Its 1966 meeting took place in Chicago, a mere two years after passage of the landmark 1964 Civil Rights Act 2 which outlawed discrimination based on race, gender, nationality, or religion, and just one year after passage of the 1965 Medicare and Medicaid Act 3,4 which forbade use of federal tax dollars to reimburse hospitals for services delivered in racially segregated facilities. While these legal and regulatory developments 5 greatly reduced conscious and deliberate health care discrimination against Black Americans, leaders of both the MCHR and the National Medical Association 6, the professional organization of Black physicians, knew that the struggle for social justice in health care was far from over 7 .

What no one could have known 50 years ago, however, was how strong unconscious racial bias would influence the quantity and quality of health care Black Americans would receive in a society now desegregated by law.

\section{Implicit bias and US health care disparities}

In the early 2000s, the Institute of Medicine of the National Academy of Sciences convened an expert committee of clinicians and social scientists to critically review the scientific evidence on racial and ethnic (in the US, the latter refers to residents of Hispanic, or Latino/a ancestry, exclusively) healthcare disparities, and as appropriate, propose steps to address the disparities. The committee's 2003 report defined a healthcare "disparity" as "racial or ethnic differences in the quality of healthcare that are not due to access-related factors, or clinical needs, [patient] preferences, and appropriateness of interventions" 8 (p. 3-4). Based on its review of hundreds of studies published during the previous three decades, the committee concluded the following:

"Evidence of racial and ethnic disparities...is, with few exceptions, remarkably consistent across a range of illnesses and healthcare; the disparities remain even after adjusting for socioeconomic differences, co-morbidities, and healthcare access factors;... the disparities in healthcare emerge from bias against minorities, greater clinical uncertainty when interacting with minority patients, and beliefs (or stereotypes) held by the provider about the behavior or health of minorities" 8 (p. 5).

According to the committee, the last of these, negative stereotypes that many healthcare providers hold toward racial and ethnic minorities, are among the most challenging barriers to overcome. This is largely because, in contemporary American society, the majority of healthcare providers endorse racially egalitarian principles and are likely to resist suggestions that negative racial/ethnic stereotypes influence their interactions with racial/ethnic minority patients or clinical decision-making.

The cognitive psychologist, John Dovidio ${ }^{9}$, reflected the general consensus in his discipline when positing that stereotyping is a universal process of social categorization by which people use salient physical (e.g., race, ethnicity, and sex) to acquire, process, and recall information about others as efficiently as possible in order to respond in ways they consider appropriate. Such stereotypes, however, are almost always systematically biased given that a salient physical attribute (e.g., skin color or sex) often becomes the primary basis for drawing inferences about other unseen, but value-laden, attributes of individuals. These unseen attributes might include, for example, the person's "intelligence", "honesty", and "trustworthiness". Importantly, the valence ("good" or "bad") of these inferred attributes is powerfully shaped at the subconscious level by how dominant social groups describe their own members (usually positively) in relation to members of subordinate social groups (usually less positively) 10,11. Thus, despite sincerely holding egalitarian racial attitudes (i.e., no explicit bias) at the 
conscious level, many White Americans, including healthcare providers, hold non-egalitarian racial attitudes (i.e., implicit bias) at the unconscious level by virtue of long term 12 exposure to cultural conditioning that subtly depicts dark-skinned people as intellectually and culturally inferior to Whites.

Thus, in their first clinical encounter, both the White physician and his/her Black patient may eye each other warily, each more or less aware of how history has shaped their views of each other. In some ways, then, a cross-racial, doctor-patient interaction can be "the strangest of all encounters" both because of what is ultimately at stake for the patient and because the incipient clinical relationship can be so easily derailed. Prospects for achieving a good clinical outcome depend on the doctor's technical competence and ability to empathize with the patient complemented by the patient's belief that the doctor has his/her best interest at heart. However, findings from the groundbreaking Institute of Medicine report 8 suggest that a significant gap still exists between the racially egalitarian values of US healthcare professionals and their actual practices. The sizeable increase in the US non-white population (especially Asians and Latinos) in recent decades underscores the importance of further investigating, and then working to improve cross-racial/ethnic encounters in healthcare.

\section{Diverse healthcare experiences in a diverse America}

In 1990, the total US population was 248.7 million; in 2010, it was 308.8 million, an increase of $19 \%$. During these 20 years, the non-Hispanic White population increased by $11 \%$ (from 199.7 million to 223.6 million); the Black population increased by $23 \%$ (from 30 million to 38.9 million); the Asian American population increased by 53\% (from 6.9 million to 14.7 million); and the Hispanic population increased by $56 \%$ (from 22.4 million to 50.5 million). American Indians increased by $33 \%$ (from 1.9 million to 2.9 million), similar to the $32 \%$ increase (from 365,000 to 540,000 ) for Hawaiian/Pacific Islanders (data from US Census Bureau; https://www.census.gov). This increasing racial and ethnic diversity of the US population underscores the importance of having a healthcare workforce that can competently deal with such diversity.

In a 2007 survey of 4,334 randomly selected US adults, age 18+ years, Blendon et al. 13 compared perceptions of the quality of physician care among 14 racial and ethnic groups to those of nonHispanic Whites. With the exception of American Indians $(\mathrm{N}=102)$, each pan-racial group contained slightly more than 1,000 respondents. Seven dimensions of perceived quality of care were examined. These included care provided by the regular physician or other health care provider; wait times for medical appointments; whether physicians spent enough time with them; whether physicians listened carefully to them; whether physicians explained things in a way they could understand; whether they had problems communicating with their physicians; and whether they felt comfortable asking questions. Ten of the 14 groups were significantly less likely $(\mathrm{p}<0.05)$ than Whites to report that their care was excellent or good. Other important survey findings included the following: $66 \%$ of Whites said their physician spent enough time with them "very often", compared to $56 \%$ of US-born Black Americans, 50\% of Mexican Americans, and 45\% of Chinese Americans. Seventy-seven percent of Whites said their physician listened to them "carefully", compared to $65 \%$ of US-born Blacks, $67 \%$ of Mexican Americans, and 61\% of Chinese Americans. And, finally, 81\% of Whites said their physician explains things in a way they can understand "very often", compared to $76 \%$ of US-born Blacks, $69 \%$ of Mexican Americans, and 59\% of Chinese Americans. While controlling for demographic factors, socio-economic resources, and as appropriate, English fluency narrowed some of the differences in perceived quality of care between Whites and racial/ethnic minorities, the authors nonetheless concluded the following: "...programs and policies that focus on ameliorating the problems confronting these groups need to reflect... the unequal experiences and needs that individual minority groups face" 13 (p. 516).

\section{Physician explicit and implicit bias}

If implicit bias by healthcare professionals has assumed more importance than explicit bias in recent decades, this does not mean that explicit bias is no longer a problem. In a study of physicians' perceptions of "post-angiogram" patients, for example, van Ryan \& Burke 14 found that physicians rated 
Blacks and poorer patients significantly lower than Whites and more affluent patients on intelligence, "friendship worthiness", and likelihood to adhere to medical advice. These differences persisted after controlling for patients' age, education, clinical and personality characteristics. Explicit bias against Blacks and working class patients has also been found among mental healthcare professionals. In a phone-based experiment, Kugelmass 15 investigated the effect of mental health seekers' race, class, and gender on the accessibility of 320 randomly selected, licensed psychotherapists based in New York City. Each psychotherapist received voicemail messages from one Black "middle class" and one White "middle class" caller of the same gender, or from one Black "working class" and one White "working class" caller of the same gender. The social class of the caller was cued by his/her vocabulary, grammar and accent. The caller's race was cued by his/her name and accent. All callers stated they had private health insurance coverage. Among "middle class" callers, $28 \%$ of Whites and $17 \%$ of Blacks received appointment offers, compared to only $8 \%$ for both Black and White "working class" callers.

Racial healthcare disparities in how physicians manage pain are well documented. Physicians are more likely to prescribe analgesics for White patients than for Black patients $16,17,18,19$. In a recent opinion piece 20 , a White medical student discussed how the "silent curriculum" taught her to treat patients differently based on their race. On the question of pain management, she wrote:

"When I arrived in the hospital... I learned that among two patients in pain waiting in an emergency department examination room, the white one is more likely to get medications and the black one is more likely to be discharged with a note documenting narcotic-seeking behavior...” 20 (p. 1909).

Blacks are falsely believed to be biologically more capable of tolerating pain than Whites. This belief was also significantly correlated with racial bias in (hypothetical) treatment recommendations. For non-White medical students and residents, however, false beliefs about biological differences, by race, in pain tolerance were not correlated with treatment recommendations.

As the above correlational studies 14,15,21 suggest, it is not clear how much of the "race effect" in physicians' management of patients' pain is due to explicit rather than implicit bias. Explicit bias must be involved to some degree, however, given that the false (and fully conscious) belief among even young physicians and medical students that Blacks are biologically less sensitive to pain than Whites is not rare 21. On the other hand, if implicit racial bias undercuts racial egalitarian values in physicians' pain management decisions, a recent study by Burgess et al. 22 suggests that the high "cognitive load" (i.e., complex, time-pressured decision-making that taxes working memory) physicians routinely carry could create openings for unconscious negative stereotypes of Blacks to influence decisions. The authors tested this possibility in a web-based experiment. They randomly assigned physicians to read vignettes about either a Black or White patient under low vs. high cognitive load "conditions", following which they were asked to indicate their likelihood of prescribing opioids to treat the patient's chronic low back pain. In the "high" cognitive load condition, physicians had to perform a concurrent task (memorizing a pattern of dots) under time pressure. Male physicians were less likely to prescribe opioids to Blacks under high cognitive load, but more likely to do so under low cognitive load. Female physicians were more likely to prescribe opioids for Blacks under both conditions.

Why cognitive load would influence how male and female physicians manage pain for Black compared to White patients is not clear, but a number of studies indicate that females $23,24,25$, including female physicians 26,27 , score higher on empathy than their male counterparts. These gender differences in empathy (i.e., the ability to see and respond emotionally to events from another's point of view) have been observed in studies that measured empathy using multi-dimensional questionnaires 26,27 as well MRI recordings of activation of neural networks 25,26 known to underlie human empathy. Whether the findings by Burgess et al. 22 regarding differences in how female and male physicians tend to manage pain in Black patients are generalizable across time, location and specialty can only be determined by future research. However, their findings clearly suggest that situational factors, such as high cognitive load, may play an important role in precipitating unconscious non-egalitarian clinical decision-making by some physicians 28,29 .

The next section provides a more depth look at how the demographic characteristics of physicians influence their implicit bias scores; how the patient's race/ethnicity influences physicians' implicit bias scores; how physicians' implicit bias scores influence doctor-patient communication; and how physicians' implicit bias influences patients' satisfaction with medical care. The measurement of implicit bias will be discussed first. 


\section{Physician implicit bias: measurement, correlates, and the doctor-patient relationship}

Implicit bias refers to a stereotype (often negative) held by an observer toward members of a racial or ethnic minority group that lies beyond a person's conscious control. The unconscious association between a specific set of negative attributes and the racial/ethnic minority group in question is well practiced and therefore automatic 30 . The standard measure of implicit bias is the Implicit Association Test (IAT) ${ }^{31}$. The IAT is a computer based, key-stroke, reaction time measure of the differential speed that negative attributes like "lazy" are associated with, for example, Blacks in contrast to Whites; and conversely, the differential speed that positive attributes like "intelligent" are associated with Whites in contrast to Blacks. An unconscious "pro-white" bias exists if, over a series of trials, the individual presses a designated computer key faster when the image of a White person is paired with a "positive" attribute than when that same attribute is paired with the image of Black person. IAT scores range from -2 to +2 . When Blacks and Whites are being compared, a positive score indicates a "pro-white bias; a negative score indicates a "pro-black" bias; and zero indicates "neutral." A positive score $>0.50$ is said to indicate substantial "pro-white" bias 32 .

Using the IAT and audiotape measures of doctor-patient communication during routine office visits by patients with 40 primary care physicians in an urban setting, Cooper et al. 33 examined associations between physician implicit bias toward Blacks and Whites, in general, and also their implicit bias toward "generic" Black and White patients' regarding their likely compliance with medical advice. The physicians' mean "generic race" IAT score was $+0.26(\mathrm{p}<0.002)$, indicating a "moderate" pro-white bias. Their mean "compliant patient" IAT score of $+0.29(\mathrm{p}<0.001)$ also indicated "moderate" pro-white bias. The 25 female physicians had lower (but not statistically significant) pro-white bias scores (IAT $=+0.22$ ) than their 15 male counterparts $(\mathrm{IAT}=+0.35)$ for "generic race". Female physicians also had lower (but not statistically significant) pro-white bias scores than their male counterparts for "compliant patient", IAT $=+0.21$ vs. +0.42 , respectively. For "generic race", the 19 White physicians (IAT score $=+0.32$ ) and the 12 Asian American physicians (IAT score $=+0.41$ ) had higher (overall $\mathrm{p}<0.07$ ) pro-White bias scores than the 9 Black physicians (IAT score $=-0.05$ ). IAT scores for "compliant patient" also varied significantly $(\mathrm{p}<0.01)$ by physician race: White $(+0.47)$, Asian American ( +0.20$)$, and Black (-0.01). Finally, the 10 physicians who identified as "politically conservative" had higher $(\mathrm{p}<0.09)$ mean "generic race" IAT scores $(+0.53)$ than the 25 physicians who identified as "liberal" (IAT $=+0.26)$. The "compliant patient" IAT score also reflected a greater, but not statistically significant $(\mathrm{p}<0.37)$, pro-white bias among "conservative" physicians $(+0.41)$ vs. "liberal" physicians $(+0.27)$.

The audiotapes were scored to determine, among other things, the degree of physician "verbal dominance" and also "patient-centered" communication 33,34,35. For Black patients, generic proWhite bias by physicians was associated with greater physician verbal dominance; a reduced sense that the physician respected them; a lower "liking" of, and confidence in, the physician; and a lower likelihood of recommending the physician to others. Negative stereotyping of Black patients by physicians as "less compliant" than White patients was associated with longer office visits, slower physician speech, less patient centered communication, and less trust and confidence in the physician. For White patients, generic pro-white bias was associated with greater physician verbal dominance but also enhanced feelings that the physician liked and respected them. Also, for White patients, a prowhite physician bias for "compliant patient", was associated with an enhanced sense that they could help decide the treatment plan, shorter office visits, faster physician speech, greater patient centered communication, and a greater willingness to recommend the physician to others. The generalizability of these findings to other health care settings, and to actual treatment recommendations by physicians, are questions for future research; however, at a minimum, these findings document that verbal and non-verbal manifestations of unconscious negative stereotypes of Black patients by physicians influence how Black patients feel about the physician and what the latter's reputation is likely to be in the Black community 36.

To date, only one published study of implicit bias against Latinos by physicians was found. Blair et al. 37 investigated implicit and explicit bias against both Latinos and African Americans in a sample of 210 White primary care providers (PCPs) and 190 White community members (CMs) residing in 
Metropolitan Denver, Colorado. Unlike most other studies of physician implicit bias which tend to focus on medical residents, 30\% of the PCPs in this study had between 11-20 years of clinical experience and $21 \%$ had more than 21 years of clinical experience. In keeping with prior research 38 , implicit bias (IAT) scores, and scores from a paper and pencil measure of explicit bias, were uncorrelated for both PCPs or CMs in this study. Both the PCPs and the CMs demonstrated moderately high pro-white implicit bias scores: Latino vs. White IAT score for PCPs was +0.33 ( $p<0.001$ ), and that for CM's was +0.29 ( $p<0.001$. The mean Black vs. White IAT score for PCPs was +0.27 ( $<<0.001)$, and that for CMs was $+0.26(\mathrm{p}<0.001)$.

Explicit and implicit bias scores toward Latinos were not correlated with PCP age, gender, medical specialty, or years of professional experience. Since PCPs and CMs recruited from the same clinics did not differ from each other in either explicit or implicit scores, the authors concluded that the "moderately high", but still substantial, pro-white bias scores observed for the PCPs reflected broader community prejudices. Importantly, about $18 \%$ of PCPs showed no implicit bias toward Latinos, and 28\% showed no implicit bias toward African Americans. This led the authors to ask: "What allows these providers to have attitudes that are both implicitly and explicitly egalitarian? Can this be taught?” 37 (p. 95). The final section of this paper addresses this question.

\section{Is implicit bias among healthcare professionals malleable?}

Based on an extensive review of controlled laboratory studies on the malleability of implicit bias, Dasgupta 39 concluded, optimistically, that implicit bias can be reduced through one of two mechanisms - a "training" mechanism (to gain more cognitive control over the negative stereotype) or an "environmental" intervention whereby individuals voluntarily surround themselves with "positive" and counter-stereotypic images and information about the "outgroup." By repeatedly making mental associations between attributes that are positively valued by mainstream society with members of a historically marginalized group, the unconscious connection between "bad" things and that group is weakened. This is what is meant by "training effect". The environmental intervention, on the other hand, involves increasing the exposure of persons who endorse racial/ethnic egalitarian values to images and works by highly accomplished members of stigmatized groups. Preliminary study findings indicate that both mechanisms reduce implicit bias scores in carefully controlled, pre vs. post-test study designs 39 .

Whereas Dasgupta's 39 review dealt primarily with studies of college students, van Ryan et al. 29 draw upon similar empirically based psychological insights when discussing strategies to reduce implicit bias among healthcare professionals. One important strategy they propose is "reduce cognitive load" among clinicians. Research confirms that when cognitive capacity is taxed, individuals are less able to override automatic processing of racial categorizing and stereotyping 40,41. As challenging as change in this area will be, reducing physician stress levels caused by incessant time pressures would likely improve both patient care and physician wellbeing 42 . Van Ryan et al. ${ }^{29}$ also argue for skill building programs to assist healthcare providers to become more "empathic" with poor and racial/ethnic minority patients, to see the world, as it were, through the eyes of these patients 42,43 . Among the several useful environmental interventions van Ryan et al. 29 propose is the need to significantly increase racial/ethnic diversity at all levels of healthcare organizations to better promote positive intergroup contact. This last point reiterates Dasgupta's 39 emphasis on the importance of "populating" all spaces with visible examples of successful racial/ethnic minorities. In healthcare settings, especially, this should reduce stereotype threat 44 among racial/ethnic minority patients while at the same time facilitating prejudice reduction among lower, middle, as well as upper occupation level Whites who are generally unaccustomed to seeing persons of color in positions of authority 45 .

\section{Conclusion}

Fifty years after passage of the 1960s' landmark Civil Rights era legislation, the problem of racial and ethnic discrimination in US health care persists. Though it hardly lessens the seriousness of 
the problem, racial/ethnic discrimination in healthcare in 21st century America is more likely to be unconscious than conscious. Studies of unconscious bias in healthcare have focused largely on Black Americans, and while this focus should not be abandoned, the recent growth of non-Black racial/ethnic minorities (e.g., Latinos/as and Asians) in the US calls for broadening the lens on the problem of racial/ethnic discrimination in US health care. In addition, US research on discrimination in health care still focuses largely on race 8,29,33,44 (though studies focused on anti-Latino/a discrimination are slowly increasing 37 ) to the neglect of gender and social class. Available evidence 22 suggests that the gender of the physician can play an important role in clinical decision-making; so might the gender of the patient. Similarly, available research 15 suggests that a patient's social class matters when seeking health care, and it is not at all clear how much of the extant bias against poor/working class patients is explicit rather implicit. In sum, research on discrimination in health care, in the US and in other multi-racial societies such as Brazil, would benefit from an intersectionality perspective 46. Patients, after all, are not simply Black/White/bi-racial (or Latino/a, Asian, etc.), male or female, poor or middle class. Patients possess all of these social identities, simultaneously, and each influences how they present themselves to health care providers and how health care providers respond to them. Therefore, going forward, more complex and more holistic conceptualizations of how discrimination manifests in health care settings are needed if we are to reduce, and ultimately, eliminate it.

\section{Conflicts of interests}

None.

\section{References}

1. Dittmer J. The good doctors: the medical committee for human rights and the struggle for social justice in health care. New York: Bloomsbury Press; 2009.

2. Loevy RD, editor. The civil rights act of 1964: the passage of the law that ended racial segregation. Albany: State University of New York Press; 1997.

3. Barton DB. Civil rights and Medicare: historical convergence and continuing legacy. In: Cohen $\mathrm{AB}$, Colby DC, Wailoo KA, Zelizer JE, editors. Medicare and Medicaid at 50: America's entitlement programs in the age of the affordable care act. New York: Oxford University Press; 1998. p. 21-38.

4. Reynolds PP. The federal government's use of Title VI and Medicare to racially integrate hospitals in the United States, 1963 through 1967. Am J Public Health 1997; 87:1850-8. 
5. Quadagno J, McDonald S. Racial segregation in southern hospitals: how Medicare broke the back of segregated health services. In: Green E, editor. The new deal and beyond: social welfare in the south since 1930. Athens: University of Georgia Press; 2003. p. 120-37.

6. The National Medical Association's contribution to the Selma-Montgomery March. J Natl Med Assoc $1965 ; 57: 243-4$.

7. Barton DB. Health care divided: race and healing a nation. Ann Arbor: University of Michigan Press; 1999.

8. Smedley BD, Stith AY, Nelson AR, editors. Unequal treatment: confronting racial and ethnic disparities in health care. Washington DC: The $\mathrm{Na}-$ tional Academies Press; 2003.

9. Dovidio JF. Stereotyping. In: Wilson RA, Keil FC, editors. The MIT encyclopedia of the cognitive sciences. Cambridge: MIT Press; 1999. p. 804-6.

10. Dovidio JF, Gaertner SL. On the nature of contemporary prejudice: the causes, consequences, and challenges of aversive racism. In: Eberhardt JL, Fiske ST, editors. Confronting racism: the problem and the response. Thousand Oaks: Sage Publications; 1998. p. 3-32.

11. Vescio TK, Gervais SJ, Heiphetz L, Bloodhart B The stereotypic behaviors of the powerful and their effects on the relatively powerless. In: Nelson TD, editor. Handbook of prejudice, stereotyping, and discrimination. New York: Taylor \& Francis Group; 2009. p. 247-66.

12. Levy SR, Hughes JM. Development of racial and ethnic prejudice in children. In: Nelson TD, editor. Handbook of prejudice, stereotyping, and discrimination. New York: Taylor \& Francis Group; 2009. p. 23-44

13. Blendon RJ, Buhr T, Cassiday EF, Perez DJ, Sussman T, Benson JM, et al. Disparities in physician care: experiences and perceptions of a multi-ethnic America. Health Aff (Millwood) 2008; 27:507-17.

14. van Ryan M, Burke J. The effect of patient race and socioeconomic status on physicians' perceptions of patients. Soc Sci Med 2000; 50:813-28.

15. Kugelmass H. "Sorry, I'm not accepting new patients": an audit study of access to mental health care. J Health Soc Behav 2016; 57:168-83.

16. Cleeland CS, Gonin R, Baez L, Loehrer P, Pandya $\mathrm{KJ}$. Pain and treatment of pain in minority patients with cancer. The Eastern Cooperative Oncology Group Minority Outpatient Pain Study. Ann Intern Med 1997; 127:813-6.
17. Cintron A, Morrison RS. Pain and ethnicity in the United States: a systematic review. J Palliat Med 2006; 9:1454-73.

18. Anderson KO, Green CR, Payne R. Racial and ethnic disparities in pain: causes and consequences of unequal care. J Pain 2009; 10:1187-204.

19. Goyal MK, Kuppermann N, Cleary SD, Teach SJ, Chamberlain JM. Racial disparities in pain management of children with appendicitis in emergency departments. JAMA Pediatr 2015; 169:996-1002.

20. Brooks KC. A piece of my mind: a silent curriculum. JAMA 2015; 313:1909-10.

21. Hoffman KM, Trawalter S, Axt JR, Olive MN. Racial bias in pain assessment and treatment recommendations, and false beliefs about biological differences between blacks and whites. Proc Nat Acad Sci U S A 2016; 113:4296-301.

22. Burgess DJ, Phelan S, Workman M, Fu SS, Widome $R$, van Ryan M. The effect of cognitive load and patient race on physicians' decisions to prescribe opioids for chronic low back pain: a randomized trial. Pain Med 2014; 15:965-74.

23. Decety J, Svetlova M. Putting together phylogenetic and ontogenetic perspectives on empathy. Dev Cogn Neurosci 2012; 2:1-24.

24. Derntl B, Finkelmeyer A, Eickhoff S, Kellermann T, Falkenberg DI, Schneider F, et al. Multidimensional assessment of empathic abilities: neural correlates and gender differences. Psychoneuroendocrinology 2010; 35:67-82.

25. Schulte-Rüther M, Markowitsch HJ, Jon Shah N, Fink GR, Piefkea M. Gender differences in brain networks supporting empathy. NeuroImage 2008; 42:393-403.

26. Hojat M, Gonnella JS, Nasca TJ, Mangione S, Vergare M, Magee M. Physician empathy: definition, components, measurement, and relationship to gender and specialty. Am J Psychiatry 2002; 159:1563-9.

27. Gleichgerrcht E, Decety J. Empathy in clinical practice: how individual dispositions, gender, and experience moderate empathic concern, burnout, and emotional distress in physicians. PLoS One 2013; 8:e61526.

28. Workman M, Lesser MF, Kim J. An exploratory study of cognitive load in diagnosing patient conditions. Int J Qual Health Care 2007; 19:127-33.

29. van Ryan M, Burke J, Dovidio JF, Phelan SM, Saha $\mathrm{S}$, Malat J, et al. The impact of racism on clinician cognition, behavior, and clinical decision making. Du Bois Rev 2011; 8:199-218. 
30. Zarate MA. Racism in the 21st century. In: Nelson TD, editor. Handbook of prejudice, stereotyping, and discrimination. New York: Taylor \& Francis Group; 2009. p. 387-406.

31. Greenwald AG, Poehlman TA, Uhlmann EL, Banaji MR. Understanding and using the implicit association test: III. Meta-analysis of predictive validity. J Pers Soc Psychol 2009; 97:17-41.

32. Project Implicit. https://implicit.harvard.edu (accessed on 05/Nov/2016).

33. Cooper LA, Roter DL, Carson KA, Beach MC, Sabin JA, Greenwald AG, et al. The associations of clinicians' implicit attitudes about race with medical visit communication and patient ratings of interpersonal care. Am J Public Health 2012; 102:979-87.

34. Roter DL, Stewart M, Putnam SM, Lipkin Jr. M, Stiles W, Inui TS. Communication patterns of primary care physicians. JAMA 1997; 277:350-6.

35. Roter DL, Larson S. The relationship between residents' and attending physicians' communication during primary care visits: an illustrative use of the Roter Interaction Analysis System. Health Commun 2001; 13:33-48.

36. Sorkin DH, Ngo-Metzger Q, De Alba I. Racial/ ethnic discrimination in health care: impact on perceived quality of care. J Gen Intern Med 2010; 25:390-6.

37. Blair IV, Havranek EP, Price DW, Hanratty R, Fairclough DL, Farley T, et al. Assessment of biases against Latinos and African Americans among primary care providers and community members. Am J Public Health 2013; 103:92-8.

38. Greenwald AG, Banaji MR. Implicit social cognition: attitudes, self-esteem, and stereotypes. Psychol Rev 1995; 102:4-27.

39. Dasgupta N. Mechanisms underlying the malleability of implicit prejudice and stereotypes: the role of automaticity and cognitive control. In: Nelson TD, editor. Handbook of prejudice, stereotyping, and discrimination. New York: Taylor \& Francis Group; 2009. p. 267-84.
40. Burgess DJ. Are providers more likely to contribute to healthcare disparities under high levels of cognitive load? How features of the healthcare setting may lead to biases in medical decision making. Med Decis Making 2010; 30:246-57.

41. Green LA, Wyszewianski L, Lowery JC, Kowalski CP, Krein SL. An observational study of the effectiveness of practice guideline implementation strategies examined according to physicians' cognitive styles. Implement Sci 2007; 2:41.

42. Batson CD, Polycarpou MP, Harmon-Jones E, Imhoff HJ, Mitchener EC, Bednar LL, et al. Empathy and attitudes: can feeling for a member of a stigmatized group improve feelings toward the group? J Pers Soc Psychol 1997; 72:105-18.

43. Galinsky AD, Moskowitz GB. Perspective-taking: decreasing stereotype expression, stereotype accessibility, and in-group favoritism. J Pers Soc Psychol 2000; 78:708-24.

44. Aronson J, Burgess D, Phelan SM, Juarez L. Unhealthy interactions: the role of stereotype threat in health disparities. Am J Public Health 2013; 103:50-6.

45. Pettigrew TF, Tropp LR. How does intergroup contact reduce prejudice? Meta-analytic tests of three mediators. Eur J Soc Psychol 2008; 38:922-34.

46. Schulz AJ, Mullings L, editors. Gender, race, class \& health: intersectional approaches. San Francisco: John Wiley \& Sons; 2006. 


\section{Resumo}

Em 2003, um comitê do Instituto de Medicina da Academia Nacional de Ciências dos Estados Unidos resumiu centenas de estudos documentando o fato de minorias raciais americanas, e principalmente os afro-americanos, receberem cuidados de saúde piores para uma ampla gama de doenças, em comparação com seus concidadãos brancos. Tais diferenças raciais persistem mesmo depois de ajuste para fatores sociodemográficos e para a capacidade dos pacientes de pagar pela assistência. O comitê concluiu que os estereótipos negativos inconscientes dos médicos contra afro-americanos, $e$ talvez contra outras pessoas de cor, provavelmente contribuem para essas disparidades. O artigo faz uma revisão seletiva de estudos publicados desde 2003 sobre a provável contribuição do preconceito inconsciente dos médicos americanos para as desigualdades nos cuidados de saúde. Todos os estudos usaram o Teste de Associação Implícita, que quantifica a velocidade relativa com que os indivíduos associam atributos positivos como "inteligentes" aos brancos, comparados com os negros ou latinos. Além de avaliar atitudes inconscientes dos médicos em relação aos pacientes, alguns estudos analisaram as dimensões comportamentais e afetivas da comunicação médico-paciente, como a "dominância verbal" dos médicos e o fato dos pacientes se sentirem, ou não, respeitados. Os estudos revisados detectaram um viés inconsciente "pró-branco" nas atitudes e na interação dos médicos com os pacientes, embora algumas evidências sugiram que os médicos negros e as médicas podem ser menos propensos a esse tipo de viés. O contato social limitado entre médicos brancos e minorias étnico-raciais fora do contexto clínico e a premência do tempo com que os médicos lidam muitas vezes durante encontros com pacientes com problemas de saúde complexos podem agravar a susceptibilidade dos médicos ao preconceito inconsciente.

Assistência à Saúde; Origem Étnica e Saúde; Racismo

\section{Resumen}

En 2003, un comité del Instituto de Medicina de la Academia Nacional de Ciencia de los Estados Unidos resumió cientos de estudios que documentan el hecho de que las minorías raciales estadounidenses, especialmente los afroamericanos, reciben atención de salud peor para una amplia gama de enfermedades, en comparación con sus conciudadanos blancos. Las diferencias raciales en persisten incluso después del ajuste por factores sociodemográficos y la capacidad de los pacientes para pagar la atención. El comité concluyó que los estereotipos negativos inconscientes de los médicos contra los afroamericanos, $y$ tal vez contra otras personas de color, probablemente contribuyen a estas disparidades. El artículo es una revisión selectiva de los estudios publicados desde 2003 sobre la posible contribución de la predisposición inconsciente de los médicos estadounidenses a las desigualdades en la atención sanitaria. Todos los estudios utilizaron el Test de Asociación Implícita, que cuantifica la velocidad relativa con la que los individuos asocian atributos positivos, como "inteligente", a los blancos en comparación con los negros o latinos. Además de evaluar las actitudes inconscientes de los médicos hacia los pacientes, algunos estudios se centraron en las dimensiones conductuales y afectivas de la comunicación médico-paciente, como la "dominación verbal" de los médicos y si los pacientes se sentían respetados. Los estudios revisados encontraron un sesgo inconsciente "pro-blanco" en las actitudes e interacciones de los médicos con los pacientes, aunque algunas evidencias sugieren que los médicos negros y las mujeres pueden ser menos propensos a este sesgo. Un contacto social limitado entre los médicos blancos y las minorías raciales/étnicas fuera de los ambientes médicos, más las presiones de tiempo severas a las que suelen enfrentarse los médicos durante encuentros con pacientes que tienen complejos problemas de salud, podrían aumentar su susceptibilidad al sesgo inconsciente.

Prestación de Atención de Salud; Origen Étnico y Salud; Racismo
Submitted on 16/Jun/2016

Final version resubmitted on 05/Nov/2016

Approved on 30/Nov/2016 